\title{
Análise do perfil metabólico pré e pós deleção do gene histona deacetilase no fungo Penicillium sp.
}

\section{Daniel Y. Akiyama*, Jonas H. Costa, Taicia P. Fill.}

\section{Resumo}

Os microorganismos são as principais fontes de moléculas biologicamente ativas e terapeuticamente úteis, incluindo anticancerígenos, imunossupressores, antibióticos, inseticidas, etc. A biossíntese dos produtos naturais fúngicos é regulada por clusteres gênicos, que se encontram silenciados em condições de cultivo padrão em laboratório. Para induzir a expressão destes genes, pode-se utilizar engenharia genética. Este trabalho visa a manipulação genética dos modificadores de estrutura da cromatina, uma vez que modificações nas histonas tem um papel importante na regulação da expressão gênica.

\section{Palavras-chave:}

produtos naturais, metabolômica, ativação de clusteres biossintéticos

\section{Introdução}

O fungo Penicillium sp. apresenta um grande potencial de produção de metabólitos secundários bioativos, conforme verificado em análises funcionais do genoma deste microorganismo. Entretanto, a partir de condições padrão de cultivo em laboratório, muitas vezes não conseguimos acesso a estes produtos naturais, sendo que a maioria de seus clusteres biossintéticos encontram-se silenciados. Uma das abordagens utilizadas para promover a ativação destes clusteres gênicos é a alteração da configuração da cromatina.

Neste projeto, objetivamos a deleção do gene HdaA do fungo Penicillium $s p$., como uma estratégia para ativação da produção de produtos naturais. A comparação do perfil metabólico do fungo selvagem e do mutante será realizada por LC-MS/MS.

\section{Resultados e Discussão}

O gene HdaA, codificante para a enzima histona deacetilase, foi deletado a partir de recombinação homóloga, utilizando higromicina como marcador de seleção. O cassete de deleção foi construído a partir de recombinação homóloga em Saccharomyces cerevisiae, utilizando as regiões flanqueadoras da ORF de interesse.
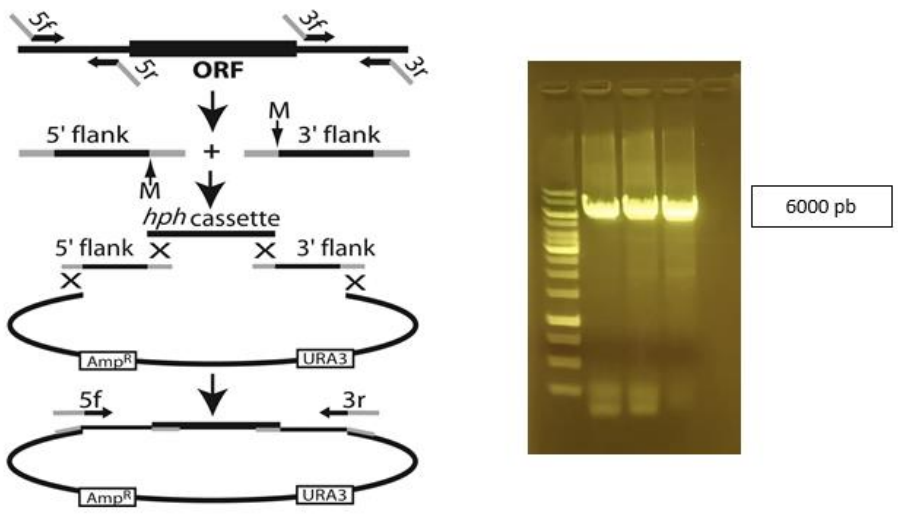

Figura 1: Estratégia para construção do cassete de deleção e gel de agarose $1 \%$ do cassete de deleção obtido para o gene HdaA

A transformação em Penicillium sp. foi realizada a partir da geração de protoplastos e mediação química com PEG. As transformações no fungo de interesse resultaram em 10 candidatos que estão sendo avaliados por PCR.
A ativação de clusteres biossintéticos também pode ser feita pela adição de moduladores epigenéticos, que alteram a expressão gênica sem alterar o genoma do microorganismo. Neste estudo, foi utilizado o ácido hidroxâmico suberoilanilida (SAHA) como inibidor da enzima histona deacetilase. Os extratos do fungo cultivado com SAHA foram analisados por LC-MS/MS e molecular networking e comparados com os extratos do fungo selvagem.

$\mathrm{Na}$ figura abaixo, é possível identificar em qual extrato cada metabólito foi obtido, além de agrupá-los em clusteres baseados em sua semelhança estrutural.
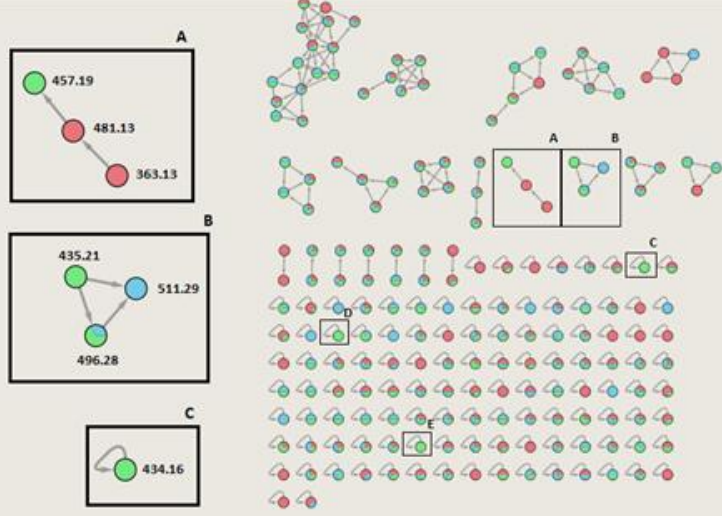

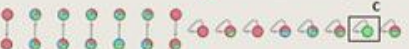

0.000000000000000

0,0000000000000

0000000000000000

040000004004000000

0404000000400000

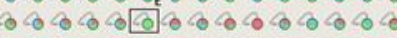

00000000000000000

$0<0$

Figura 2: Análises de molecular networking dos extratos de $P$. brasilianum cultivado com o modulador SAHA e seus controles.

A identificação dos íons de interesse está sendo realizada.

\section{Conclusões}

Os resultados preliminares evidenciam a influência da configuração da cromatina na expressão de produtos naturais fúngicos. A deleção do gene HdaA, portanto, é uma estratégia relevante para a obtenção de diversidade estrutural de produtos naturais.

\section{Agradecimentos}

Ao Laboratório de Biologia Química Microbiana LaBioQuiMi/IQ/UNICAMP e toda sua equipe e à FAPESP pelo financiamento.

${ }^{1}$ NIELSEN, J. C. et al. Global analysis of biosynthetic gene clusters reveals vast potential of secondary metabolite production in Penicillium species. Nature Microbiology, v. 2, n. 6, 3 abr. 2017. 